\title{
LANGUAGE CO-EVOLVED WITH THE RULE OF LAW
}

\author{
CHRIS KNIGHT \\ School of Social Sciences, Media and Cultural Studies, University of East London, \\ Docklands Campus, London E16 2RD, England

\begin{abstract}
Many scholars assume a connection between the evolution of language and that of distinctively human group-level morality. Unfortunately, such thinkers frequently downplay a central implication of modern Darwinian theory, which precludes the possibility of innate psychological mechanisms evolving to benefit the group at the expense of the individual. Group level moral regulation is indeed central to sexual, social and political life in all known hunter-gatherer communities. The production of speech acts would be impossible without such regulation. The challenge, therefore, is to explain on a Darwinian basis how life could have become subject to the rule of law. Only then will we have an appropriate social framework in which to contextualize our models of how language may have evolved.
\end{abstract}

\section{Language and the rule of law}

Let me begin with a self-evident point, perhaps too often taken for granted. When academics participate in conferences and debates, we find ourselves operating under the rule of law. Protocols exist. We must keep to agreed time limits, disclose our sources, accept criticism and renounce any temptation to use threats, material inducements or force. There is status competition, certainly. But status is determined on an intellectual basis by peer evaluation alone; we compete to demonstrate relevance (Sperber and Wilson 1995 [1986]; Dessalles 1998 ) in one anothers' eyes.

What applies in academic life applies wherever language is used. Protocols exist. Compared with academic discourse, informal gossip may be livelier, more relaxed, less abstract and more intimately bound up with nonlinguistic modes of expression. But despite such obvious differences, the same basic principles apply. Civilized discourse (Grice 1989: 22-40; Leech 1980; Brown and Levinson 1987 [1978]) is inseparably bound up with such things as tact, mutual face-saving and respect. What I am here terming 'the rule of law' is never just behavioral dominance exerted by certain individuals over others. It is contractual, valid only when based on mutual consent. The relevant contracts may be formal, informal or completely taken for granted (and correspondingly 
invisible). But only once such understandings are in place can any of us 'do things with words' (Austin 1978 [1955]).

This being the case, speech acts are never behavioral. On the level which matters - that is, on the level which is distinctively human - we proceed as if playing an abstract game. As in chess, moves are made within a hallucinatory world, each intervention digitally specified and effective insofar as its intention is socially recognized (Grice 1989: 86-116). To emit a signal - even to transform the entire state of play - no physical investment need be made. In a language game (Wittgenstein 1968), interventions need not be materially costly. In principle, a nod or wink might suffice. What constitutes a move is the fact that it is agreed to be one - nothing more. Abstract digital information is then transmitted - with intuitive mind reading filling in the gaps and guessing at the communicative intention (Sperber and Wilson 1986).

Language evolved among hunters and gatherers. Hunter-gatherer communities are at least as civilized as any others (Lee 1988). Artificial kinship structures are designed to ensure that sex, for example, falls under the rule of law (Morgan 1871). Ritual taboos surround matters such as incest or menstruation (Durkheim 1963 [1898]). Protocols and ritual injunctions facilitate sexual circulationrather in the way that traffic signals in a modern city ensure traffic flow (LéviStrauss 1969). Humans need rules if they are to transcend primate-style conflict. The law exists to uphold behavior of a civilized kind.

Language is inseparable from 'society' in this sense. Should law and order collapse, the social magic of words (Bourdieu 1990) would evaporate. Linguists implicitly recognize this when they make one of their most characteristic simplifying assumptions - that of a 'homogenous speech community'. The expression is Chomsky's (1965: 3), but the underlying idea is traceable to Saussure (1974 [1915]). Saussure assumed civilized, democratic conditions what cricket-players might term 'a level playing field'. This being the case, his concept of the default state for society had nothing in common with Darwin's 'survival of the fittest'. Questions of sex, power, violence and so forth fall outside the framework of rule-governed intercourse - and, therefore, have no place in language as a system. Sending a message, in Saussure's conceptual universe, is very like going to the post office: one must affix the correct stamp. Anticipating Wittgenstein, Saussure likened language in its systematic aspect to a board game such as chess.

Applied to non-human primates, not one fragment of Saussure's semiotic paradigm is relevant in any way. Chimpanzees may co-operate, particularly if related. For much of the time, group members foraging in proximity to one another may well be relaxed and sociable. Periodically, however, a ferocious fight breaks out. This may be settled eventually, but it would be stretching credulity to apply the term 'civilized' to political arrangements of this kind. Apes are under no pressure to operate within the law. They are not like human hunters and gatherers. They do not have formal kinship systems. They do not 
sustain institutional facts - facts dependent for their existence on communal belief. Whether they compete or co-operate, they inhabit only an unregulated that is, a straightforwardly Darwinian - world. In such a world, language is not theoretically possible.

\section{In defense of Darwinism}

Human society is not Darwinian; yet Darwinism must be used to explain it. In this paper, I am exploring the possibility that language evolved as an internal feature of life under the rule of law. The Darwinian thinker John Maynard Smith advanced a proposal along these lines in his 1995 book co-authored with Eörs Szathmáry - The Major Transitions in Evolution. Within this theoretical framework, 'society' became established when group-level contracts became evolutionarily stable. It was difficult to achieve this, since the work of enforcement through rewards and punishment requires specific costly investment. Contracts are vulnerable to free-riders - individuals seeking the benefits of co-operation without paying their share of the costs. Somehow, however - in at least one ancestral population - this problem was dealt with. The founding social contract survived (Maynard Smith and Szathmáry 1995).

The rule of law creates a climate of trust (Sztompka 1999). Although competition is not abolished, it assumes a different form - it must proceed within the law. Hunter-gatherers in general are self-governing egalitarians (Lee 1988). Where a community is self-governing, laws are conceptualized in moral terms. Pantheons of other worldly beings - spirits of various kinds - may be employed to represent contractual authorities (Durkheim 1965 [1912]). Alliances committed to enforcement share a common moral purpose and perspective (Alexander 1987). Competition is for moral standing within the community or alliance. Status in this context is freely accorded, not extracted by threat or coercion. Speakers gain social standing by being perceived by their peers as relevant (Dessalles 1998). It is not possible to gain such status by being secretive, devious or inscrutable. Individuals come under pressure to co-ordinate personal perspectives with wider social aims, adopting what might be termed a 'god's eye' view of the world (Boyer 2001). Once having passed through the relevant rite of passage (Van Gennep 1960 [1909]) - once having paid the costs of entry into the ritual community - adults are expected to assume responsibility in this way (Knight 1998, 1999).

When individuals trust one another and share the same perspective, they may communicate effectively without language. A barely perceptible wink can 'speak volumes' on one condition: shared understandings must already be well entrenched. A nod may be regarded as a rudimentary 'up/down' switch; a wink is closer to 'on/off'. It is immediately clear that digital switches of this kind presuppose trust: two parties engaged in a violent argument could not conceivably communicate in so effortless a way. On the other hand, a network 
of trusting conspirators might well extend their repertoire of switches, recruiting additional parts of the body such as hands, tongue or lips.

Many animals can produce subtle movements of their hands, tongues and lips. Indeed, since mastication and ingestion depends on such mobility, it would be strange if they could not. The odd thing about humans is that such simple motions, evolved for non-communicative functions, have been exapted to serve purposes in communication. To grasp how unnatural and unlikely this is, let us imaginatively enter an unregulated world. Imagine being a motorist caught in a traffic jam at a city intersection where the signals have failed. Using your vehicle's right or left indicator no longer works. Even in a vehicle buzzing with digital equipment it would make no difference whatsoever. Nobody takes the slightest notice; nobody makes way. Your skills in signaling have become quite irrelevant. The explanation is not that the world has become cognitively deficient. It is simply that civilization has temporarily collapsed. The only solution is to use the whole vehicle, pushing, shoving and nudging your way through. Unless you are prepared to risk colliding - a method persuasive only insofar as costs are incurred - you may remain for hours in the same place.

There are no traffic signals or other moral regulators in nature (Dawkins 1989). When chimpanzees vocalize in a public space, they therefore use the whole vehicle. Pant hoots and waa barks are 'body language' in this sense, the audible component inseparable from visually salient and in other ways unmistakable signs. In these as in other indexical displays, the costs of signaling may rise or fall in accordance with risks of exploitation or deceit (Searcy and Nowicki 2005). But in a Darwinian context, no signal can be completely free of charge. Each must pass a test of quality and reliability, evaluated on an analog scale. An inevitable consequence is that evolution in the direction of language is ruled out.

But if ape signals are body language, can we define speech by contrast as 'head language'? Certainly, no other species communicates so narrowly in and through the head. Chomsky is surely right on this point: language is 'internal', offering a window into the autonomous realm of 'mind'. But Chomsky's natural science approach to the study of mind is not the only possible one. It may be better to do social science. In his book, The Cultural Origins of Human Cognition, Michael Tomasello (1999) identifies 'mind' with a particular capacity for social cognition. No ape is capable of bi-directional mind reading or continuously maintained joint attention. Apes don't point at things; humans from an early age do. In short: the human brain is wired up to correlate perspectives; ape brains are not. Since an ape cannot view itself from another's perspective, it is unable to represent to itself its own mental states. Apes, in short, are incapable of what Tomasello calls 'intersubjectivity'.

For apes, this is adaptive because they inhabit a Darwinian world - one lacking in moral regulation. Each strives to extract information from its rivals while divulging as little as it can in return. The extent to which facial 
inscrutability is positively selected in primates has been demonstrated by a remarkable comparative study. The structure of non-human primate eyes - when compared with their human counterparts - is clearly adaptive. Humans divulge direction of gaze thanks to a dark iris rendered salient against the background of a brilliant white sclera. With their dark irises in equally dark surrounds, by contrast, the eyes of mature primates are evidently not designed to give much away. Whereas the human design facilitates openness and transparency, that of adult primates appears specifically designed to avoid divulging direction of gaze to nearby conspecifics (Kobayashi and Kohshima 2001).

The structure of the eyes must surely be connected to the fact that although chimpanzees co-operate, their status is not determined by the positive esteem of peers. It is not freely allocated. On the contrary, it is determined by establishing dominance at others' expense, either individually or by forming an alliance. Alliance partners are valued for their fighting ability and talents at Machiavellian scheming. Admittedly, strategies that humans might regard as socially creative do have a place, as De Waal (1996) has been at pains to show. But a consistently honest, open, trusting and socially responsible ape would not get far.

By nature, humans are competitive or co-operative according to need. But at least on a face-to-face level, status competition among humans assumes nonDarwinian forms. Admittedly, class societies - capitalism in particular - appear at least superficially to embody Darwinian principles. But humans in general do not inhabit a Darwinian world. Egalitarian hunter-gatherers long ago transcended that level of complexity. Under what I am here calling 'the rule of law', status must be gained by making contributions valued by the community as a whole.

\section{Conclusion}

The 'human revolution' culminated in something remarkable - the establishment of the rule of law (Dunbar, Knight and Power 1999). Apes do not recognize group level social contracts. When they signal, consequently, they must intervene in physical and biological reality. There is no other kind of reality in which they can intervene. Each animal can make a difference only physically, only with its body - with signals inseparable from the body. Chimpanzee waa-barks and pant-hoots are examples of this. They are indices of bodily and emotional states - direct behavioral interventions, with direct behavioral impact and consequences.

By contrast, a human linguistic utterance - a 'speech act' - is an intervention in a different kind of reality, known by philosophers as 'institutional reality'. 'Institutional facts' exist because it is collectively believed that they do. Examples are money, marriage, football scores and underworlds (Searle 1996). A speech act, like a move in a board game, is internal to reality of this kind (Saussure 1974 [1915]; Wittgenstein 1968). Signals need produce no physical or 
behavioural impact - only a shift in perspective. A shift of this kind is an alteration within a peculiar domain, neither objective nor subjective in the ordinary sense. Things are 'seen' or 'judged' differently, and to that extent reality (the world as jointly constructed) has changed (Searle 1996). When human life became subject to the rule of law, participation in this kind of reality became possible for the first time. Language first emerged in the form of cryptic 'nods' and 'winks' - mutually understood signs - for navigating within this novel domain. Such entities were no longer evolving in a Darwinian biological environment. The normal laws of signal evolution therefore no longer applied. Wastefulness in signals (Zahavi 1991) was no longer under positive selection. The paradoxes of language evolution correspondingly dissolved.

Today, no-one doubts that language has a genetic component. But respect for the law cannot be explained by this or that instinct, cognitive module or postulated gene. Where behavioural strategies provoke counter-strategies, contrasting strategic outcomes must necessarily emerge on the basis of identical genes. Only once a new strategy has become evolutionarily stable does it in turn alter selection pressures, modifying the trajectory of genetic evolution accordingly. The law cannot be enforced partially or half-heartedly - no such strategy will prove evolutionarily stable. In that sense, our hunter and gatherer ancestors cannot have won the revolution gradually, making progress only through 'descent with modification'. At a certain point, once conditions were ripe, they established the rule of law in the only way they could. For the individuals concerned, it would have been all or nothing. In one small population at least, their resistance to lawlessness succeeded - and turned the world upside down (Mellars and Stringer 1989; Knight 1991; Boehm 2001).

Language is dependent on civilized, rule-governed behavior. This cannot be assumed; it must be explained (Knight, Power and Watts 1995; Power and Aiello 1997; Dunbar, Knight and Power 1999). Ancestral humans surely had good Darwinian reasons to band together in enforcing the rule of law. Any explanation must therefore be in terms of standard Darwinian theory.

\section{References}

Alexander, R. D. (1987). The Biology of Moral Systems. New York: Aldine de Gruyter.

Austin, J. L. (1978 [1955]). How to Do Things with Words. Oxford: Oxford University Press.

Boehm, C. (2001). Hierarchy in the Forest. The evolution of egalitarian behavior. Cambridge, MA: Harvard University Press.

Boyer, P. (2001). Religion Explained. New York: Basic Books.

Bourdieu, P. (1991). Language and Symbolic Power. Cambridge: Polity Press.

Brown, P. and S. C. Levinson (1987 [1978]). Politeness: some universals in language usage. Cambridge: Cambridge University Press. Reprinted from: 
Goody, E. (Ed.), Questions and politeness: strategies in social interaction (pp. 56-324). Cambridge: Cambridge University Press.

Chomsky, N. (1965). Aspects of the Theory of Syntax. Cambridge, Mass.: MIT Press.

Dawkins, R. (1989). The Selfish Gene, 2nd edn. Oxford: Oxford University Press.

Dessalles, J.-L. (1998). 'Altruism, Status and the Origin of Relevance', in J. R. Hurford, M. Studdert-Kennedy and C. Knight (Eds.), Approaches to the Evolution of Language (pp. 130-47). Cambridge: Cambridge University Press.

De Waal, F. B. M. (1996). Good Natured. The origins of right and wrong in humans and other animals. Cambridge, MA: Harvard University Press.

Dunbar, R., C. Knight and C. Power (Eds.) (1999). The Evolution of Culture. Edinburgh: Edinburgh University Press.

Durkheim, E. (1963 [1898]). La prohibition de l'inceste et ses origines. L'Année Sociologique, 1, 1-70. Reprinted as Incest. The nature and origin of the taboo, trans. E. Sagarin. New York: Stuart.

Durkheim, E. (1965 [1912]). The Elementary Forms of the Religious Life. New York: Free Press.

Durkheim Knight, C., C. Power and I. Watts (1995). The human symbolic revolution: A Darwinian account. Cambridge Archaeological Journal, 5(1), 75-114.

Grice, H. P. (1989). Studies in the Way of Words. Cambridge, MA: Harvard University Press.

Knight, C., (1991). Blood Relations. Menstruation and the origins of culture. New Haven and London: Yale University Press.

Knight, C., (1998). Ritual/speech coevolution: a solution to the problem of deception. In J. R. Hurford, M. Studdert-Kennedy and C. Knight (Eds.), Approaches to the Evolution of Language: Social and cognitive bases (pp. 68-91). Cambridge: Cambridge University Press.

Knight, C., (1999). Sex and language as pretend-play. In R. Dunbar, C. Knight and C. Power (Eds.), The Evolution of Culture (pp. 228-247). Edinburgh: Edinburgh University Press.

Kobayashi, H., and S. Kohshima (2001). 'Unique Morphology of the Human Eye and Its Adaptive Meaning: Comparative Studies on External Morphology of the Primate Eye'. Journal of Human Evolution, 40/5, 419-35.

Lee, R. B. (1988). 'Reflections on Primitive Communism', in T. Ingold, D. Riches, and J. Woodburn (Eds.), Hunters and Gatherers, I. History, Evolution and Social Change (pp. 252-268). Chicago: Aldine).

Leech, G. (1980). Language and tact. In: Explorations in semantics and pragmatics. Pragmatics and Beyond 4 (pp. 79-117). Amsterdam: John Benjamins. 
Lévi-Strauss, C. (1969), The Elementary Structures of Kinship. London: Eyre and Spottiswoode.

Maynard Smith, J. and E. Szathmáry (1995). The Major Transitions in Evolution. New York: W. H. Freeman.

Mellars, P. A. and C. Stringer (Eds.), (1989). The Human Revolution: Behavioural and Biological Perspective in the Origins of Modern Humans. Edinburgh: Edinburgh University Press.

Morgan, L. H. (1871). Systems of Consanguinity and Affinity of the Human Family. Washington: Smithsonian Institution.

Power, C. and L. C. Aiello (1997). Female proto-symbolic strategies. In L. D. Hager (Ed.), Women in Human Evolution (pp. 153-171). New York and London: Routledge.

Saussure, F. DE (1974 [1915]). Course in General Linguistics, trans. W. Baskin. London: Fontana/Collins.

Searcy, W. A. and S. Nowicki (2005). The Evolution of Animal Communication. Princeton and Oxford: Princeton University Press.

Searle, J. R. (1996). The Construction of Social Reality. London: Penguin.

Sperber, D. and D. Wilson (1986). Relevance. Communication and cognition. Oxford: Blackwell.

Stompka, P. (1999). Trust. Cambridge: Cambridge University Press.

Tomasello, M. (1999). The Cultural Origins of Human Cognition. Cambridge, MA: Harvard University Press.

Van Gennep, A. (1960 [1909]). The Rites of Passage. London: Routledge and Kegan Paul.

Wittgenstein, L. (1968). Philosophical Investigations, trans. G. E. M. Anscombe. Oxford: Blackwell.

Zahavi, A. (1991). On the definition of sexual selection, Fisher's model, and the evolution of waste and of signals in general. Animal Behaviour, 42, 501-3. 